\title{
Atmospheric teleconnections between the Arctic and the eastern Baltic Sea regions
}

\author{
Liisi Jakobson $^{1,2}$, Erko Jakobson ${ }^{2}$, Piia Post ${ }^{1}$, and Jaak Jaagus ${ }^{1}$ \\ ${ }^{1}$ University of Tartu, Tartu, Estonia \\ ${ }^{2}$ Tartu Observatory, Tõravere, Estonia \\ Correspondence to: Liisi Jakobson (liisi.jakobson@ut.ee)
}

Received: 31 March 2017 - Discussion started: 6 April 2017

Revised: 30 September 2017 - Accepted: 9 October 2017 - Published: 14 November 2017

\begin{abstract}
The teleconnections between meteorological parameters of the Arctic and the eastern Baltic Sea regions were analysed based on the NCEP-CFSR and ERA-Interim reanalysis data for 1979-2015. The eastern Baltic Sea region was characterised by meteorological values at a testing point (TP) in southern Estonia $\left(58^{\circ} \mathrm{N}\right.$, $\left.26^{\circ} \mathrm{E}\right)$. Temperature at the $1000 \mathrm{hPa}$ level at the TP have a strong negative correlation with the Greenland sector (the region between $55-80^{\circ} \mathrm{N}$ and $20-80^{\circ} \mathrm{W}$ ) during all seasons except summer. Significant teleconnections are present in temperature profiles from 1000 to $500 \mathrm{hPa}$. The strongest teleconnections between the same parameter at the eastern Baltic Sea region and the Arctic are found in winter, but they are clearly affected by the Arctic Oscillation (AO) index. After removal of the AO index variability, correlations in winter were below \pm 0.5 , while in other seasons there remained regions with strong $(|R|>0.5, p<0.002)$ correlations. Strong correlations $(|R|>0.5)$ are also present between different climate variables (sea-level pressure, specific humidity, wind speed) at the TP and different regions of the Arctic. These teleconnections cannot be explained solely with the variability of circulation indices. The positive temperature anomaly of mild winter at the Greenland sector shifts towards east during the next seasons, reaching the Baltic Sea region in summer. This evolution is present at 60 and $65^{\circ} \mathrm{N}$ but is missing at higher latitudes. The most permanent lagged correlations in $1000 \mathrm{hPa}$ temperature reveal that the temperature in summer at the TP is strongly predestined by temperature in the Greenland sector in the previous spring and winter.
\end{abstract}

\section{Introduction}

Over the past half a century, the Arctic has warmed at about twice the global rate (IPCC, 2013), a phenomenon called the Arctic amplification (AA). At the same time, a significant decrease in sea ice extent has occurred in all calendar months since 1979 (Simmonds, 2015), which has been declared to have a leading role in recent AA by some scientists (e.g. Screen and Simmonds, 2010; Francis and Vavrus, 2012). On the other hand, Perlwitz et al. (2015) disagree with the common assumption that sea ice decline is primarily responsible for the amplified Arctic tropospheric warming. They found that from October to December, the main factors responsible for the Arctic deep tropospheric warming are (1) the recent decadal fluctuations and (2) long-term changes in sea surface temperatures. These two factors are located outside the
Arctic. According to Sato et al. (2014) warm southerly advection is favourable for retreating sea ice over the Barents Sea and warming of air aloft, whereas sea ice decline would result in warming over the Barents Sea because of anomalous turbulent heat fluxes. Screen et al. (2012) found that sea ice concentration and sea surface temperature explain a large portion of the observed Arctic near-surface warming, whereas remote sea surface temperature changes explain the majority of observed warming aloft. As the energy budget of the Arctic is highly dependent on energy exchange with lower latitudes, the changes in atmospheric and oceanic circulation play an important role in a variety of heat conservation changes in the Arctic, most prominently expressed in sea ice volume variations. The observed enhanced warming of the Arctic, referred to as the AA, is expected to be related 
to further changes that impact mid-latitudes and the rest of the world (Jung et al., 2015; Walsh, 2014). These Arctic influences could be direct, as the advection of cold and dry air from over the ice-covered areas to the neighbouring territories, but it could also be through teleconnections - the large-scale patterns of high- and low-pressure systems and circulation anomalies that cover vast geographical areas and reflect the non-periodic oscillations of the climate system.

Teleconnection as a term was first used by Ångström (1935). Wallace and Gutzler (1981) defined teleconnections as significant simultaneous correlations between the time series of meteorological parameters at widely separated points on the Earth; the essence of a teleconnection is that a climatic process may influence the Earth's system elsewhere (Liu and Alexander, 2007).

Teleconnections between the Arctic and mid-latitude regions have been the focus of research for many years and several reviews about the Arctic sea ice impact on the global climate (Budikova, 2009; Vihma, 2014) or Eurasian climate (Gao et al., 2015) have been published. Budikova (2009) stated that the size of the response of the climate of remote regions to changes in the Arctic has been found to be linked linearly, but the forcing direction non-linearly. Less ice in the Arctic results in a significant decrease in the speed of the westerlies and the intensities of storms poleward of $45^{\circ} \mathrm{N}$ (Budikova, 2009). Many studies suggest that the Arctic sea ice decline increases the probability for circulation patterns resembling the negative phase of the Arctic Oscillation (AO) and North Atlantic Oscillation (NAO) indices in winter (Vihma, 2014). However, there is debate as to whether the reduction in the autumn Arctic sea-ice-induced negative $\mathrm{AO} / \mathrm{NAO}$ index can persist into winter, and it has been suggested that winter atmospheric circulation is more closely associated with changes in the winter Arctic sea ice (Gao et al., 2015). Several studies have demonstrated relationships between warming and/or ice decline, and mid-latitude weather and climate extremes (Handorf et al., 2015; Coumou et al., 2014; Tang et al., 2013; Petoukhov et al., 2013; Francis and Vavrus, 2012; Petoukhov and Semenov, 2010). Others have analysed whether these associations are statistically and/or physically robust (Hassanzadeh et al., 2014; Screen et al., 2014; Barnes et al., 2014; Screen and Simmonds, 2013, 2014; Barnes, 2013), while some investigations suggest that the apparent associations may have their origin, in part, in remote influences (Perlwitz et al., 2015; Sato et al., 2014; Peings and Magnusdottir, 2014; Screen et al., 2012; Petoukhov and Semenov, 2010).

The linkages between the Arctic and mid-latitudes depend on geographical region, season, and other impacts. There are certain geographical regions in the Arctic that have greater amount of warming and the influence of these is more investigated. Arctic warming over the Barents and Kara seas and its impacts on the mid-latitude circulations have been widely discussed (Dobricic et al., 2016; Semenov and Latif, 2015; Kug et al., 2015; Sato et al., 2014). Another particular re- gional warm core (Screen and Simmonds, 2010) is the East Siberian and Chukchi seas, which is related to severe winters over North America (Kug et al., 2015; Lee et al., 2015). Screen and Simmonds (2010) also described the third particular regional warm core - northeast Canada and Greenland which has been less investigated. Wu et al. (2013) focused on winter sea ice concentration west of Greenland, including the Labrador Sea, Davis Strait, Baffin Bay, and Hudson Bay, and found that winter sea ice concentration west of Greenland is a possible precursor for summer atmospheric circulation and rainfall anomalies over northern Eurasia. If we look at the regions in the mid-latitudes then potential Arctic teleconnections with Europe are less clear than with North America and Asia (Overland et al., 2015). The linkages between the Arctic and mid-latitudes depend also on season. Summer is exceptional season when the weather conditions are less affected by large-scale atmospheric circulation both in midlatitudes and in the Arctic. But the influence of the increase in late summer open water area is directly contributing to a modification of large-scale atmospheric circulation patterns (Overland and Wang, 2010).

The eastern Baltic Sea region features very variable weather conditions due to its location in the climatic transition zone between the North Atlantic and the Eurasian continent. The region is also close to the Arctic or even part of it (depending on defining the borderlines) and certainly has a direct Arctic influence. The weather in the region depends highly on the position of the polar front: it can be located northward as well as southward of the area. According to the Second Assessment of Climate Change for the Baltic Sea Basin (BACC II, 2015), significant changes have occurred in climate parameters, which could be associated with largescale atmospheric circulation. Intensity of the zonal circulation, i.e. the westerlies, has increased during the cold period (NDJFM), especially in February and March. After the 1980s there has been significant temperature increase in the Baltic Sea region (BACC II, 2015), which has not been equal throughout a year. The highest increase in air temperature is typical for spring (MAM) season. Although a remarkable warming has also been present in winter (DJF), it is not significant due to a very high temporal variability (Jaagus, 2006). A tendency of increasing precipitation in winter and spring was detected in the Baltic Sea region during the latter half of the 20th century, possibly increasing the risk of extreme precipitation events. There is some evidence that the intensity of storm surges may have increased in some parts of the Baltic Sea in recent decades, and this has been attributed to long-term shifts in the tracks of some cyclone types rather than to a long-term change in the intensity of storminess (BACC II, 2015).

It is known that fluctuations of the climatological parameters in the Baltic Sea region are strongly affected by the atmospheric circulation variability described by the teleconnection indices of NAO and AO (BACC II, 2015). There is no clear understanding of the reasons for the changes in these in- 
dices or climatic parameters in the Baltic Sea region in most recent time. One of the reasons for incomplete understanding is the non-stationarity of the NAO spatial pattern and the temporal correlations (Lehmann et al., 2011, 2017). It is natural to assume that changes in the Arctic climate system have an effect on the eastern Baltic Sea region and vice versa due to their close proximity. Our aim is to clarify how the climatic parameters in the eastern Baltic Sea and Arctic regions are associated. Knowledge of such connections helps to define regions in the Arctic that could be with higher extent associated with the eastern Baltic region climate change.

Our analysis is designed as follows. We selected one grid point (the testing point, TP) to represent the eastern Baltic Sea region and to find correlations between climate parameters at this point and in the Arctic cap to find the regions of mutual connections. Next, we calculate the partial correlations with various teleconnection indices as control factors to get rid of the known atmospheric circulation variability. To compare broad atmospheric circulation patterns, we calculate geopotential heights differences between cold and mild winters. Due to longer memory of non-atmospheric components of climate system we compute by season-lagged correlations between climate parameters.

The objective of this paper is to indicate the relationships between meteorological parameters of the Arctic region and the TP. By tracking down the teleconnections between the rapidly changing Arctic region and the TP we can get valuable information about possible future trends in the eastern Baltic Sea region even if the changes in both regions were caused by a third factor.

\section{Data and methodology}

We used monthly mean reanalysis data from the Climate Forecast System Reanalysis (CFSR) on a $0.5^{\circ} \times 0.5^{\circ}$ horizontal grids provided by the National Centers for Environmental Prediction (NCEP). For the period 1979-2010, 6hourly data of CFSR version 1 (Saha et al., 2010) were used for calculating monthly means; for 2011-2015, 6-hourly data of CFSR version 2 were used (Saha et al., 2014). For reproducibility, we repeated all calculations using ERA-Interim data (Dee et al., 2011). Mostly, these two models showed very similar results. In this paper, only NCEP-CFSR results are shown, only disagreements between models are pointed out in the Results section. The following parameters were analysed: temperature at 1000, 850, 500, and $250 \mathrm{hPa}$ level; sea-level pressure (SLP); geopotential heights from 1000 to $100 \mathrm{hPa}$; specific humidity and wind speed at $1000 \mathrm{hPa}$; and sea ice concentration (SIC). Monthly means and seasonal means (DJF, MAM, JJA, SON) were calculated from the 6hourly data. Monthly mean wind speed was calculated as a scalar average.
The teleconnection indices we applied in our analyses were chosen according to the possible influence due to the geographical position of the centres of action of the teleconnection patterns over the North Atlantic-Eurasian region. The following indices were chosen: (1) the North Atlantic Oscillation (NAO), which is the dominant mode of atmospheric variability in the North Atlantic sector throughout the year (Barnston and Livezey, 1987); (2) the Arctic Oscillation (AO), which is usually defined as the first EOF (empirical orthogonal function) of the mean sea-level pressure field in the Northern Hemisphere (Ambaum et al., 2001); (3) the Scandinavian pattern (SCA), which consists of a primary circulation centre over Scandinavia, with two other weaker centres of action with the opposite sign, one over the north eastern Atlantic and the other over central Siberia to the southwest of Lake Baikal (Bueh and Nakamura, 2007); (4) the East Atlantic pattern (EA), which consists of a north-south dipole of anomaly centres spanning the North Atlantic from east to west (Barnston and Livezey, 1987); (5) the East Atlantic/West Russia pattern (EA/WR), which consists of four main anomaly centres: Europe, northern China, central North Atlantic, and north of the Caspian Sea; (6) the Polar/Eurasia pattern (PEU) consists of height anomalies over the polar region, and opposite anomalies over northern China and Mongolia. (7) Additionally, Pacific Decadal Oscillation (PDO), which is the dominant year-round pattern of monthly North Pacific sea surface temperature (SST) variability, was included. Although its geographical centres are far from the Baltic Sea region, Uotila et al. (2015) found that PDO correlated significantly with the ice concentration and temperature of Baltic Sea. All indices were downloaded from the NOAACPC database (http://www.cpc.noaa.gov).

We assume that, because of a high spatial correlation between meteorological conditions in the eastern Baltic Sea region, it is reasonable to choose one testing point (TP) that represents the region. Lehmann et al. (2011) used the same method by selecting Hamburg-Fuhlsbüttel to represent the temperature evolution of the Baltic Sea area as correlation coefficients for the seasonal mean air temperature between Hamburg and different sub-basins ranged from 0.8 to 0.9 . We selected TP in southern Estonia with coordinates $58^{\circ} \mathrm{N}$, $26^{\circ} \mathrm{E}$. The correlation coefficient for the seasonal mean air temperature at $1000 \mathrm{hPa}$ and SLP (not shown) between the TP and different sub-basins of the eastern Baltic Sea is mostly higher than 0.85 (Fig. 1). The highest correlation is observed in winter and the lowest in summer.

We analysed the reanalysis data with the Grid Analysis and Display System (GrADS). We calculated linear correlation coefficients to reveal teleconnections between the Arctic region and the TP of the eastern Baltic Sea region. In this paper we use only linear Pearson correlations, non-linear correlations are not included. We define the Arctic region here as the region northward of $55^{\circ} \mathrm{N}$. A larger region than usual (Arctic cap from polar circle or $70^{\circ} \mathrm{N}$; July $10^{\circ} \mathrm{C}$ isotherm) helps to analyse results that lay partly outside the usually defined 


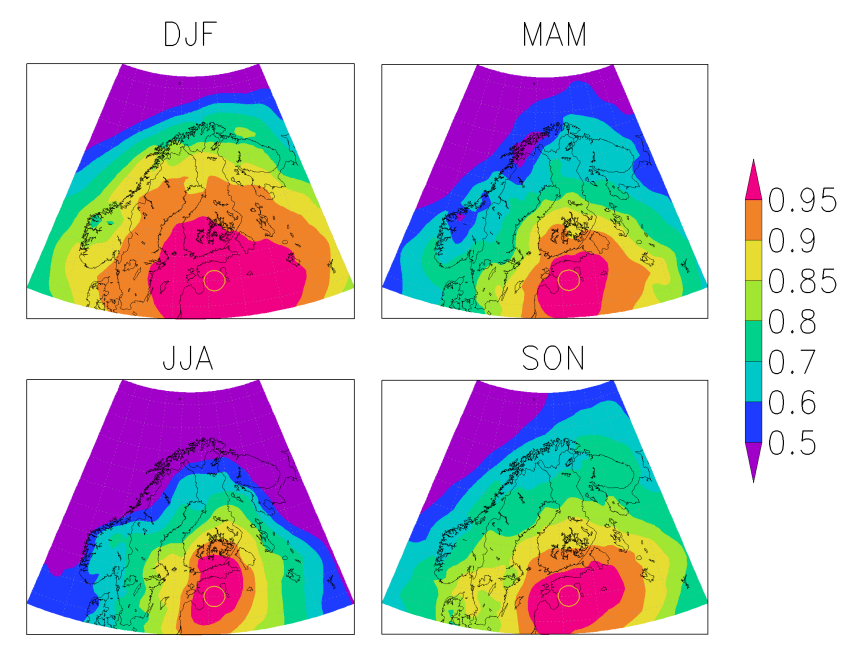

Figure 1. Correlation maps of air temperature at the $1000 \mathrm{hPa}$ level for the testing point in the Baltic Sea region.

Arctic region. For correlations with the TP, the first correlation input was taken at the TP and the second in the Arctic region.

All presented correlations are significant at the confidence level $95 \%$; only strong correlations $|R|>0.5$ are discussed in this paper. We used $F$ tests to assess the significance of correlations. Autocorrelation in the time series is taken into account by using effective number of degrees of freedom for correlation, calculated using lag-one autocorrelation of residuals. For comparison of averages, we used $t$ tests assuming equal variances.

Detrending of seasonal time series was done to ascertain that the correlations are not caused by mutual trends in input variables using the following formula:

$Y_{i}=X_{i}-\left(k \cdot\right.$ year $\left.+b-X_{\text {average }}\right)$.

Therefore, linear trends for each parameter at each grid point were calculated for each season and all correlations were calculated twice - first using the regular and second the detrended data. Detrending did not change general patterns of correlations with TP - only negative correlation in the Greenland region intensified slightly. All discussed correlations of the regular data were also significant in analysis of detrended data. As we are exploring the connections that include longterm climatic trends such as global warming, we present in this paper only correlations of the regular, non-detrended data.

The next step in the analysis was to remove from the correlations the effect of atmospheric teleconnections which could be described by known teleconnection indices. For that purpose, partial correlations between selected atmospheric variables with the controlling effect of the teleconnection indices were calculated as follows:

$$
R_{A B \mid C}=\frac{R_{A B}-R_{A C} \cdot R_{B C}}{\sqrt{\left(1-R_{A C}^{2}\right) \cdot\left(1-R_{B C}^{2}\right)}} .
$$

Cold and mild winters were defined as years when the winter average temperature differed the whole period average more than one standard deviation at a geographical point in the Greenland sector $\left(70^{\circ} \mathrm{N}, 60^{\circ} \mathrm{W}\right)$. Accordingly, cold winters were 1983, 1984, 1989, 1990, 1992, and 1993; mild winters were 1980, 1985, 1986, 2003, 2007, 2009, 2010, and 2011.

The last phase of the analysis was to calculate the lagged correlation coefficients with the purpose of revealing the possible delayed dependences between the atmospheric variables of the Arctic region and the TP. For the lagged correlation, the second parameter was taken by lag months earlier than the first parameter.

\section{Results}

\subsection{Spatial correlations of climatic variables}

Climatic variables at separate grid points are usually not independent, but correlations in space depend highly on the distance and climatic variables. For example, for temperature, the dependence in space stays significant for longer distances than for precipitation as the processes of their formation are different. But besides the short distance correlation of climatic parameters between the TP and the surrounding grid points, there are also vast areas far from the TP, still having significant correlations (Fig. 2). The strongest correlations are detected in winter when temperature at the $1000 \mathrm{hPa}$ level at the TP has a positive correlation over a large area, covering nearly the whole northern Eurasia, with the maximum $(R>0.5)$ in northern Europe, on the eastern European Plain and in central Siberia. At the same time, an area of a strong negative correlation $(R<-0.5)$ is found in the Greenland sector. Hereinafter, we define the Greenland sector as region between $55-80^{\circ} \mathrm{N}$ and $20-80^{\circ} \mathrm{W}$. A similar correlation pattern, but of lower magnitude, is also present in spring and autumn. The pattern of spatial correlation for temperature at the $1000 \mathrm{hPa}$ level in summer is different. The area of positive correlation is much smaller than in winter, mostly covering only Europe, but a negative correlation is detected in the central Arctic and western Siberia.

Specific humidity at the $1000 \mathrm{hPa}$ level has a similar pattern of correlations to temperature in the same seasons. The largest differences are observed in Siberia in spring with about $20 \%$ higher correlation in temperature than in specific humidity. Wind speed at the $1000 \mathrm{hPa}$ level at the TP has the highest correlation in winter, while the areas of a positive correlation in Europe and North Atlantic and of a negative correlation in the central Arctic and the Greenland sector are strictly distinct. During the other seasons the spatial correlation is much lower. There is a strong positive correlation 


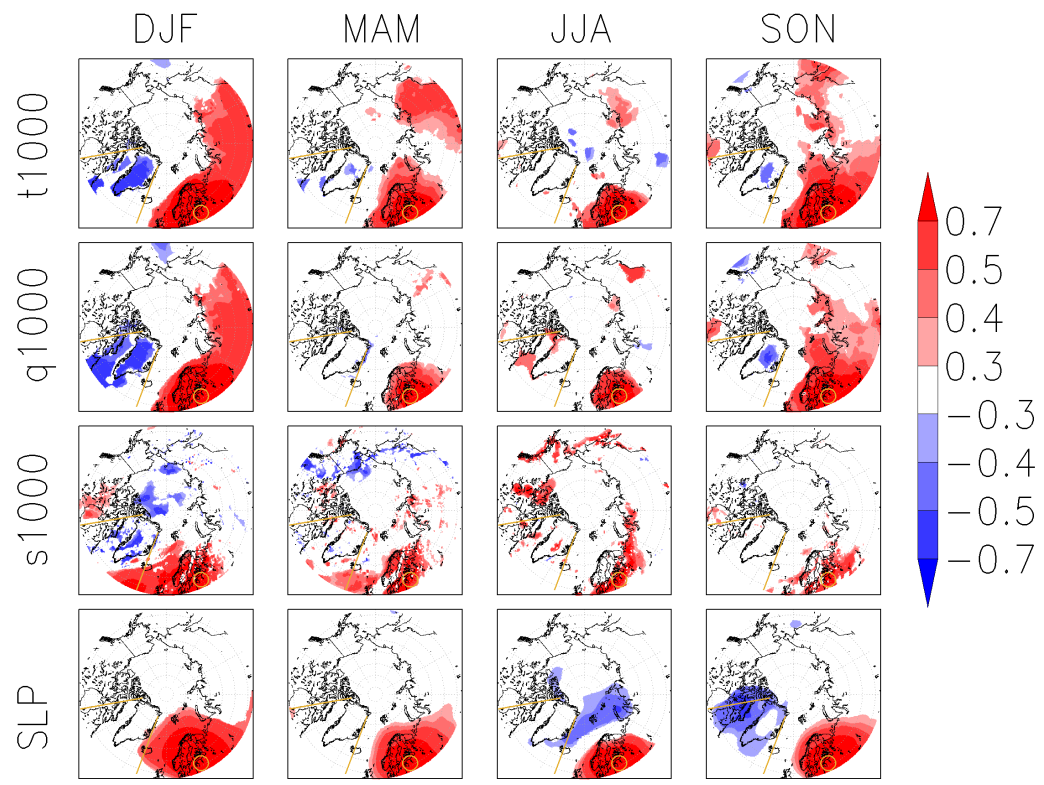

Figure 2. Correlation maps between seasonal mean $1000 \mathrm{hPa}$ temperature (t1000), specific humidity (q1000), wind speed (s1000), and SLP measured at the TP (the yellow circle) and in the whole Arctic region. Columns represent seasons; all presented correlations are significant at the confidence level $95 \%$. The Greenland sector $\left(20-80^{\circ} \mathrm{W}, 55-80^{\circ} \mathrm{N}\right)$ borders are marked with two yellow lines.

Table 1. Areal average and minimum and maximum of seasonal correlations between VAR1 at TP and VAR2 at the Greenland sector $\left(20-80^{\circ} \mathrm{W}, 55-80^{\circ} \mathrm{N}\right)$.

\begin{tabular}{llrrrr|rrrr|rrrr}
\hline & & \multicolumn{4}{c}{ Average } & \multicolumn{3}{c|}{ Minimum } & \multicolumn{3}{c}{ Maximum } \\
\cline { 3 - 12 } VAR1 & VAR2 & DJF & MAM & JJA & SON & DJF & MAM & JJA & SON & DJF & MAM & JJA & SON \\
\hline t1000 & t1000 & -0.41 & -0.23 & 0.15 & -0.02 & -0.63 & -0.51 & -0.22 & -0.49 & 0.03 & 0.21 & 0.44 & 0.49 \\
t850 & t850 & -0.41 & -0.26 & 0.09 & -0.02 & -0.63 & -0.46 & -0.19 & -0.34 & 0.08 & 0.06 & 0.34 & 0.48 \\
t500 & t500 & -0.32 & -0.19 & 0.24 & 0.00 & -0.52 & -0.51 & 0.02 & -0.20 & 0.09 & 0.15 & 0.49 & 0.40 \\
t250 & t250 & 0.31 & 0.20 & -0.02 & 0.00 & 0.08 & 0.02 & -0.36 & -0.29 & 0.55 & 0.39 & 0.41 & 0.28 \\
q1000 & q1000 & -0.44 & -0.20 & 0.28 & -0.04 & -0.65 & -0.50 & -0.19 & -0.53 & 0.11 & 0.09 & 0.62 & 0.45 \\
s1000 & s1000 & -0.11 & 0.02 & 0.05 & 0.01 & -0.72 & -0.58 & -0.47 & -0.36 & 0.77 & 0.67 & 0.75 & 0.42 \\
SLP & SLP & 0.15 & -0.12 & -0.25 & -0.36 & -0.25 & -0.30 & -0.43 & -0.54 & 0.51 & 0.33 & 0.16 & -0.13 \\
t1000 & SLP & -0.39 & -0.27 & -0.23 & 0.03 & -0.73 & -0.50 & -0.42 & -0.45 & 0.35 & 0.11 & -0.02 & 0.51 \\
t1000 & s1000 & -0.15 & -0.03 & -0.02 & -0.03 & -0.67 & -0.54 & -0.42 & -0.65 & 0.65 & 0.48 & 0.38 & 0.43 \\
t1000 & icec & 0.17 & 0.11 & -0.07 & 0.01 & -0.26 & -0.34 & -0.62 & -0.41 & 0.61 & 0.64 & 0.41 & 0.48 \\
s1000 & icec & 0.19 & 0.06 & 0.03 & 0.16 & -0.28 & -0.67 & -0.36 & -0.24 & 0.63 & 0.63 & 0.71 & 0.59 \\
\hline
\end{tabular}

in wind speed in summer between the TP and the Canadian Arctic Archipelago and the Bering Sea region. SLP at the TP has a significant negative correlation with SLP in the Greenland sector in autumn. Figure 2 using ERA-Interim data (not shown) gave very similar results. Detectable differences were found in central Arctic in summer and autumn when correlations with temperature and specific humidity were slightly higher in ERA-Interim than NCEP-CFSR.

The Greenland sector showed most often significant correlations with the parameters of the eastern Baltic Sea region. In Table 1 are given spatial average, minimum, and maximum values of seasonal correlations between the TP and the Greenland sector. Strong negative correlation in the Green- land sector at $1000 \mathrm{hPa}$ temperature in winter and spring decreases with altitude and turns even positive at $250 \mathrm{hPa}$ (Table 1). Specific humidity at $1000 \mathrm{hPa}$ shows quite similar values with temperature at the same level (Table 1). The correlation between wind speed at $1000 \mathrm{hPa}$ at the TP and the Greenland sector is mostly negative in winter (Fig. 2), reaching up to -0.72 (Table 1). The most significant correlation between SLP is present in autumn and summer (Fig. 2, Table 1).

Climatic variables have close relationships between themselves. If there is a climatic change in one parameter, for example in temperature, then it also causes changes in other parameters connected with it, for example in ice concentra- 
Table 2. Areal average of seasonal (winter and spring) partial correlations between $1000 \mathrm{hPa}$ temperature at $\mathrm{TP}$ and the Greenland sector $\left(20-80^{\circ} \mathrm{W}, 55-80^{\circ} \mathrm{N}\right)$ using different teleconnection indices as controlling factors.

\begin{tabular}{lrr}
\hline Index & DJF & MAM \\
\hline reg. correl. & -0.41 & -0.23 \\
AO & -0.07 & -0.10 \\
NAO & -0.10 & -0.11 \\
PDO & -0.45 & -0.26 \\
CAI & -0.41 & -0.21 \\
PEU & -0.42 & -0.18 \\
EA & -0.43 & -0.27 \\
EA/WR & -0.41 & -0.22 \\
SCA & -0.25 & -0.23 \\
\hline
\end{tabular}

tion. Similarly to correlations of the same climate variable at the TP and the Arctic (Fig. 2), there are strong correlations $(|R|>0.5)$ between different climate variables at the TP and the Greenland sector (Table 1). Correlation between the $1000 \mathrm{hPa}$ temperature at the TP and SLP shows expected results with a positive correlation in summer and negative in winter around the TP (not shown). Largest correlations with the Greenland sector are in winter, when the correlation is on average -0.39 and extremal values reach even to -0.73 . Correlations with ice concentration have quite large extremal values, reaching up to 0.71 in summer for wind speed and 0.64 in spring for temperature, but these correlations are significant only at narrow coastal areas around Greenland (not shown).

\subsection{Impact of the teleconnection indices}

To analyse the impact of the seven teleconnection indices given in Sect. 2, the average of partial correlations between $1000 \mathrm{hPa}$ temperature at TP and the Greenland sector (55$80^{\circ} \mathrm{N}, 20-80^{\circ} \mathrm{W}$ ) are shown for winter and spring in Table 2 . The influence of teleconnection indices depends strongly on a season and a parameter. Larger difference from regular correlation values means higher impact of the index. According to the definition, removing the impact may decrease, but may also increase, the correlation.

The first row of Table 2 shows the average of the regular Pearson correlation of temperature at $1000 \mathrm{hPa}$ in the region. It has the most significant values during winter and spring. Also, the impact of $\mathrm{AO}$ and $\mathrm{NAO}$ is most considerable during these seasons. Considering the correlation coefficients between seasonal mean temperatures, specific humidity, wind speed at the $1000 \mathrm{hPa}$ level and SLP at the TP, the AO indices have mostly higher correlations than the NAO indices; only in summer and autumn does SLP have a significantly higher correlation with the NAO index (not shown). Hereafter mostly only the AO index is analysed (and not the NAO index).
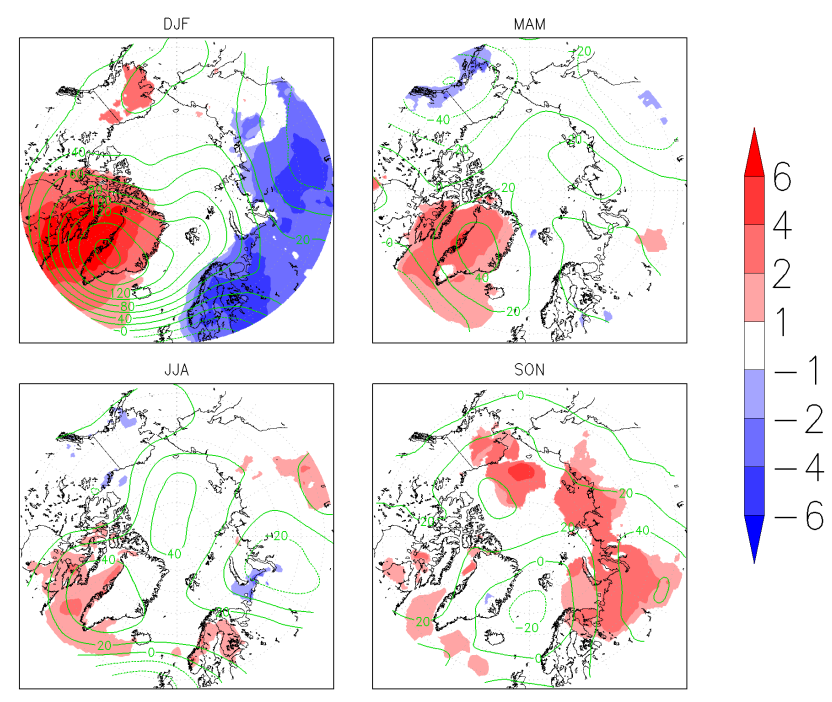

Figure 3. Seasonal difference maps (years with mild winters minus years with cold winters) in air temperature at $1000 \mathrm{hPa}$ level (shading with confidence level of $95 \%$ ), and geopotential height at $500 \mathrm{hPa}$ level (contours).

Partial correlations with the controlling factor AO index reduce the area with a statistically significant correlation around the TP in all parameters and in all seasons. This effect on the remote areas depends on the season. In winter the effects of the AO indices on spatial correlations are the strongest, up to 0.5 . In spring, the differences between partial correlations with the $\mathrm{AO}$ indices are below 0.2 in the whole region compared to the regular correlations between the TP and the Arctic. In summer and autumn, the differences are even smaller than in spring.

Partial correlation in temperature, removing the influence of the $\mathrm{AO}$ index, is below \pm 0.5 at all levels $(1000,850,500$, and $250 \mathrm{hPa}$ ) in winter, though the regular correlations are the strongest (not shown). In other seasons, regions with stronger partial correlations than \pm 0.5 remain. In summer and autumn, the AO indices have no significant influence on correlations on higher altitudes, similarly to the $1000 \mathrm{hPa}$ level.

The impact of other teleconnection indices than $\mathrm{AO}$ and NAO is much smaller. Among other indices the SCA index has the strongest impact in winter but very small impact during other seasons, while in spring the partial correlation with the PEU index decreases the value of correlation coefficient the most (except AO and NAO). The average (regular) correlation coefficients between $1000 \mathrm{hPa}$ temperature at TP and the Greenland sector during summer and autumn were only 0.15 and -0.02 , respectively, and are not discussed here.

\subsection{Comparison of winters with low and high temperature}

To compare broad atmospheric circulation patterns, we turn to the difference map of the geopotential heights of $500 \mathrm{hPa}$ 

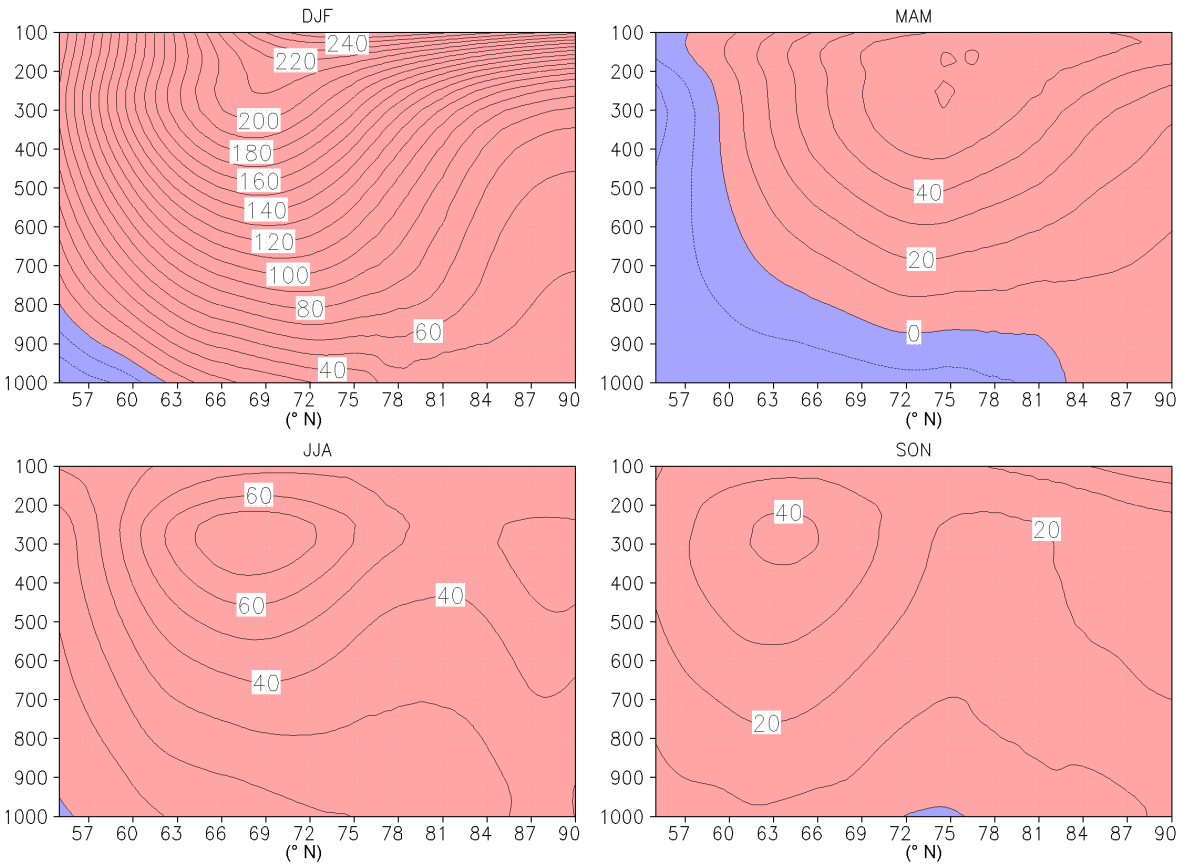

Figure 4. Differences in the mean geopotential heights between mild and cold winters along the $60^{\circ} \mathrm{W}$ vertical slice. Contour intervals are $10 \mathrm{gpm}$; blue represents negative height differences and red positive height differences.

and temperature at $1000 \mathrm{hPa}$ by subtracting the composites of cold winters (DJF) from those of mild winters (Fig. 3). The large-scale atmospheric circulation pattern in Fig. 3 shows that the geopotential heights of $500 \mathrm{hPa}$ are more than 100 gpm higher in mild winters than in cold ones. The maximum of this height anomaly is centred over the maximum of the $1000 \mathrm{hPa}$ temperature difference. The whole column (up to $500 \mathrm{hPa}$ ) of the air in the Greenland sector is warmer than at cold years. Coming down to the lower surfaces $(700 \mathrm{hPa}$, SLP, not shown), the maximum height anomaly is shifted to the east. Ensuing spring and summer also show positive values of the $1000 \mathrm{hPa}$ temperature and the geopotential heights of $500 \mathrm{hPa}$ in the Greenland sector (spring and summer in Fig. 3). In autumn the positive anomaly of $1000 \mathrm{hPa}$ temperature and geopotential heights of $500 \mathrm{hPa}$ are present in Siberia.

Along the $60^{\circ} \mathrm{W}$ vertical slice the spring atmosphere exhibits a baroclinic structure between about 60 and $82^{\circ} \mathrm{N}$ due to negative height anomalies in the lower troposphere below the $850 \mathrm{hPa}$ and with further higher the positive ones (spring in Fig. 4). Similarly to Wu et al. (2013) the vertical distribution of spring height anomalies differs from that of the previous winter when height anomalies show dominantly quasibarotropic structure. The annual evolution of $500 \mathrm{hPa}$ height differences at $60^{\circ} \mathrm{N}$ shows that the positive height anomaly at the Greenland sector shifts towards east during the next seasons, reaching Scandinavia-Baltic Sea region in summer (Fig. 5). The propagation of the mid-tropospheric anomalies in this region is non-linear: these height anomalies are signif-

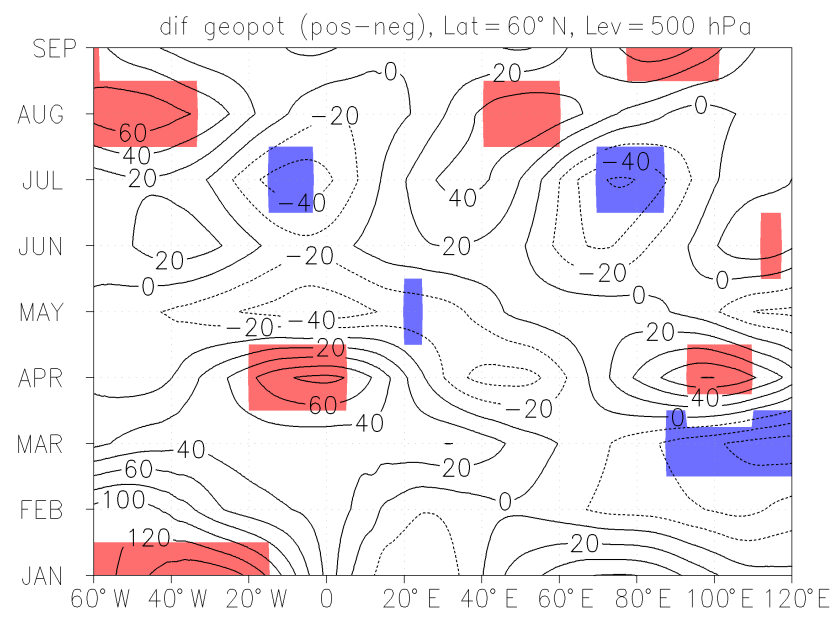

Figure 5. Evolution of $500 \mathrm{hPa}$ height differences between mild and cold winters at $60^{\circ} \mathrm{N}$; red and blue shading indicates differences at the $95 \%$ significance levels for positive and negative height, respectively.

icant only over some areas and months, and in May they are slightly negative. Also, at $65^{\circ} \mathrm{N}$ the similar pattern is present (not shown), but at 70 and $75^{\circ} \mathrm{N}$ this kind of signal propagation is missing. ERA-Interim has similar patterns at $60^{\circ} \mathrm{N}$, but without considerable positive difference at the Greenland sector in winter (not shown). 

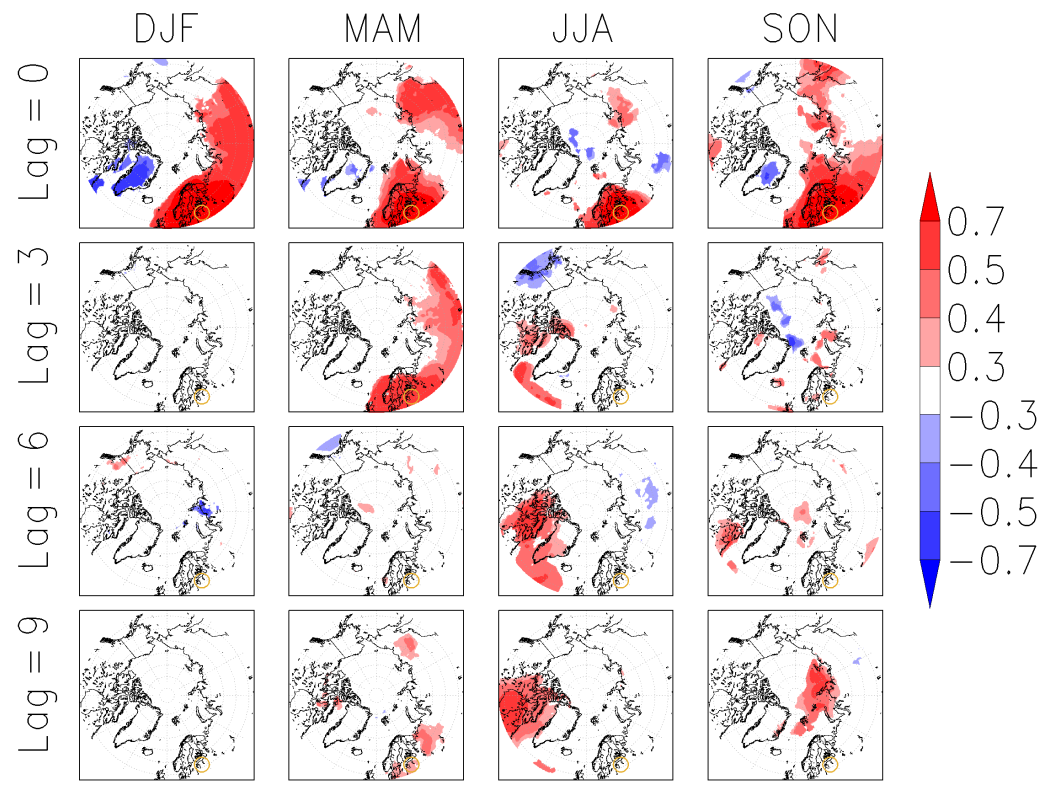

Figure 6. Lagged correlation maps between the TP (the yellow circle) and Arctic $1000 \mathrm{hPa}$ temperature: first row, lag is 0 months (no lag); second row, lag is 3 months; third row, lag is 6 months; fourth row, lag is 9 months. Columns represent seasons; all presented correlations are significant at the confidence level $95 \%$.

\subsection{Teleconnection using lagged data}

The climate system consists of various interactive components that have highly various response times. The estimated timescales in the atmosphere grow with height and reach up to months, but due to atmospheric interactions with the oceans and cryosphere, the conditions in the atmosphere may have even longer response times. For finding the effect of the previous seasons on atmospheric conditions at the TP, lagged correlations were calculated for the $1000 \mathrm{hPa}$ temperature (Fig. 6). The results show that the previous winter season has a strong effect on temperature during the following spring $(\mathrm{lag}=3)$ and summer $(\mathrm{lag}=6)$. At the same time, the winter mean temperature has almost no dependence on weather conditions during the previous seasons; there is only a small region with strong negative correlation in the Taimyr region in the previous summer $(\mathrm{lag}=6)$. There is a strong $(R>0.5)$ positive correlation between the $1000 \mathrm{hPa}$ temperatures at the TP in spring and in Eurasia during the previous winter $(\mathrm{lag}=3)$. The spring temperature is determined by the temperature of neither the previous autumn $(\mathrm{lag}=6)$ nor the previous summer $(\operatorname{lag}=9)$. Summer temperature at the TP has a strong positive correlation in the Greenland sector with the previous spring $(\mathrm{lag}=3)$, winter $(\mathrm{lag}=6)$, and autumn $(\mathrm{lag}=9)$. Autumn temperature at the TP has a strong negative correlation with the Fram Strait in the previous summer $(\mathrm{lag}=3)$ and the Taimyr region in the previous winter (lag $=9)$.

\section{Discussion}

There are vast areas in the Arctic far from the eastern Baltic Sea region that show significant correlations with meteorological parameters at the TP. Temperature at the $1000 \mathrm{hPa}$ level at the TP has a strong positive correlation $(R>0.5)$ with the eastern European Plain up to central Siberia and a strong negative correlation with the Greenland sector during all seasons except summer (Fig. 2). These patterns are similar to the correlations with the AO index (not shown) and are probably partly induced by the general circulation of the atmosphere. These correlations can be considered as an effect of stronger westerlies that carry relatively warm and moist air from the North Atlantic into Eurasia and, at the same time, cold and dry air from the central Arctic to Greenland and the Canadian Arctic Archipelago. As specific humidity and temperature are strongly coupled, specific humidity has a similar pattern of correlations as temperature. Warmer air can hold much more water vapour. The reason why summer season differs from other seasons maybe caused by a less effective large-scale circulation. Also, the circumstances are different in summertime. In summer the atmospheric energy budget is positive, there are more specific humidity and clouds, and the melting ice temperature is conserved by the melting energy of ice. Consequently, we assume that weather conditions in summer are more influenced by local factors, such as differences in local radiation and heat balances determined by local geographical peculiarities, and less affected by largescale atmospheric circulation. 
Partial correlation analyses were used as the control for the potential effects of different teleconnection indices on correlations between meteorological parameters at the TP and the Arctic. Partial correlations with the controlling factors of the $\mathrm{AO}$ and NAO indices had the strongest influence on the correlations between meteorological parameters between the TP and the Arctic region; other teleconnection indices had much smaller influence (Table 2). Budikova (2012) suggests that the AO and NAO are very closely related and the NAO is frequently referred to as a "local expression" of the AO as it dominates its structure in the Atlantic sector. Still, some scientists show different impact of NAO and AO to meteorological parameters and phenomenon. According to the review article by Bader et al. (2011), the NAO is the most important teleconnection index for investigating the impact of the Arctic sea ice changes on teleconnection patterns. The study of Ambaum et al. (2001) suggests also that because of the physical background of the NAO index it may be physically more relevant and robust for the Northern Hemisphere variability than is the AO index. Uotila et al. (2015) preferred NAO to $\mathrm{AO}$ analysing Baltic Sea ice conditions because of the centre of action that has more influence over the Baltic Sea ice conditions (Uotila et al., 2015). Thompson and Wallace (1998) claimed that the AO index is actually more strongly coupled to the Eurasian winter surface air temperature than the NAO index. Rinke et al. (2013) showed through the coupled regional climate model experiments that atmospheric largescale circulation in a winter following low September sea ice resemble a negative AO pattern. Our results show that for the correlation coefficients between the eastern Baltic Sea region and the Greenland sector, the AO index had mostly the highest impact in every season; only in summer and autumn did SLP have a significantly stronger impact with the NAO index. The strongest teleconnections between the same parameter at the eastern Baltic Sea region and the Arctic region can be found in winter, but they are clearly affected by the AO index (Table 2).

Among other teleconnection indices (except $\mathrm{AO}$ and NAO) the SCA index showed the largest impact between $1000 \mathrm{hPa}$ temperature at TP and the Greenland sector during winter (Table 2). The SCA pattern has been shown to influence precipitation, temperatures, and cyclone activity across northern Europe and Eurasia (Moore et al., 2013; Bueh and Nakamura, 2007; Seierstad et al., 2007). Uotila et al. (2015) found that the PDO index has significant impact on the Baltic Sea ice concentration although physical mechanisms linking the Baltic Sea ice with PDO are not well known (Vihma et al., 2014). We investigated the correlation between $1000 \mathrm{hPa}$ temperature at TP and the Greenland sector and removing the influence of PDO (by partial correlation) did not change the results much during any season. Removing the EA/WR index influenced the results even less although regionally the anomaly centres of the EA/WR pattern include Europe and North Atlantic. Lim (2015) analysed the EA/WR (19792012) and found that the positive (negative) EA/WR is asso- ciated with a strong cooling (warming) over the Ural Mountains of northern Russia which is much further to the east of our TP.

The comparison of 700 and $500 \mathrm{hPa}$ geopotential height differences between mild and cold winters showed that $700 \mathrm{hPa}$ geopotential height is shifted to the east. This could be due to warmer sea surface of the North Atlantic compared to the regions that lie to west of it. The positive temperature anomaly at $1000 \mathrm{hPa}$ height shifts from the Greenland sector in winter towards east reaching to Scandinavia/Baltic Sea region in summer. This could be also followed by our lagged analyses which show that the summer temperature at TP has significant correlation with Greenland sector in winter (JJA; lag =6). According to Wu et al. (2013) the summer atmospheric circulation anomalies in the northern Eurasia are associated with the previous winter SIC west of Greenland. The mechanism is based on a horseshoe-like pattern of SST anomalies in the North Atlantic that persists in winter and spring. Such an anomaly impacts on ensuing spring atmosphere over the North Atlantic which links winter-spring SIC and SST anomalies and summer atmospheric circulation anomalies over northern Eurasia, including the Baltic Sea region. This proposed mechanism supports our results.

\section{Conclusions}

Rapid warming and reduction of sea ice is going on in the Arctic. In this article, the relations between meteorological parameters of the Arctic region and the eastern Baltic Sea region are investigated, using the NCEP-CFSR and ERAInterim reanalysis data for 1979-2015. The eastern Baltic Sea region is characterized by meteorological values at the testing point $(\mathrm{TP})$ in southern Estonia $\left(58^{\circ} \mathrm{N}, 26^{\circ} \mathrm{E}\right)$. There are vast areas in the Arctic, far from the eastern Baltic Sea region, that show significant correlations with climatological parameters at the TP. The most important findings about the Arctic teleconnections with the eastern Baltic Sea region are as follows:

- The strongest teleconnections between the same parameter in the eastern Baltic Sea region and the Arctic are in winter, but they are clearly affected by the Arctic Oscillation index (AO index). After removal of the AO index variability, correlations in winter were below 0.5 , while in other seasons strong $(|R|>0.5)$ correlations mostly remain.

- Strong teleconnections are present in temperature profiles from 1000 to $500 \mathrm{hPa}$. Similarly to the $1000 \mathrm{hPa}$ level, teleconnections on higher levels are connected with the AO index variability in winter.

- Strong teleconnections are present between different climate variables at the TP and the Arctic. Temperature and wind speed at the $1000 \mathrm{hPa}$ level in the eastern 
Baltic Sea region have, in all seasons, strong teleconnections with the sea ice concentration in some regions of the Arctic Ocean. These teleconnections cannot be explained solely with the climate indices' variability.

- The annual evolution of $500 \mathrm{hPa}$ height differences (between mild and cold winter in the Greenland sector) at $60^{\circ} \mathrm{N}$ shows that the positive temperature anomaly during winter shifts towards east during the next seasons, reaching to Scandinavia/Baltic Sea region in summer. Also, at $65^{\circ} \mathrm{N}$ the similar pattern is present. At higher latitudes $\left(70\right.$ and $\left.75^{\circ} \mathrm{N}\right)$ this kind of signal propagation is missing.

- In all seasons there are strong teleconnections in temperature at $1000 \mathrm{hPa}$ at the TP with some Arctic regions from the previous seasons. The most permanent lagged correlations in $1000 \mathrm{hPa}$ temperature are in summer at the TP with the Greenland sector in the previous spring, winter, and even autumn.

In conclusion, in every season there are some regions in the Arctic that have strong teleconnection $(|R|>0.5, p<$ 0.002) with temperature, SLP, specific humidity, and wind speed in the eastern Baltic Sea region. These relationships can be explained by the $\mathrm{AO}$ index variability only in winter. In other seasons there must be other influencing factors. The positive temperature anomaly evolution of $500 \mathrm{hPa}$ height differences from the Greenland sector in winter to the Baltic Sea region in summer is present at the 60 and $65^{\circ} \mathrm{N}$ meridian and missing at higher latitudes. The lagged correlation in $1000 \mathrm{hPa}$ temperature in summer at the TP supports the results of temperature evolution. The results of this study are valuable for selecting regions in the Arctic that have the statistically largest effect on climate in the eastern Baltic Sea region.

Data availability. The reanalyses data used here are available from the NCAR-UCAR Research Data Archive (https://rda.ucar. edu/) under their data policy rules.

Competing interests. The authors declare that they have no conflict of interest.

Special issue statement. This article is part of the special issue "Multiple drivers for Earth system changes in the Baltic Sea region". It is a result of the 1st Baltic Earth Conference, Nida, Lithuania, 13-17 June 2016.

Acknowledgements. Comments of four anonymous reviewers have led to a significant improvement of this paper. This study was supported by the Estonian Research Council grant PUT (645) and institutional research funding IUT (2-16) and IUT (20-11) of the
Estonian Ministry of Education and Research. ECMWF, NCAR, and NOAA-CPC are acknowledged for data supply.

Edited by: Marcus Reckermann

Reviewed by: four anonymous referees

\section{References}

Ambaum, M. H. P., Hoskins, B. J., Stephenson, D. B.: Arctic Oscillation or North Atlantic Oscillation?, J. Climate, 14, 3495-3507, https://doi.org/10.1175/15200442(2001)014<3495:AOONAO>2.0.CO;2, 2001.

Ångström, A.: Teleconnections of Climatic Changes in Present Time, Geogr. Ann., 17, 242-258, https://doi.org/10.2307/519964, 1935.

BACC II Author Team: Second Assessment of Climate Change for the Baltic Sea Basin, Springer Open, Berlin, p. 501, 2015.

Bader, J., Mesquita, M. D. S., Hodges, K. I., Keenlyside, N., Østerhus, S., and Miles, M.: A review on Northern Hemisphere seaice, storminess and the North Atlantic Oscillaion: Observations and projected changes, Atmos. Res., 101, 809-834, 2011.

Barnes, E. A.: Revisiting the evidence linking Arctic Amplification to extreme weather in midlatitudes, Geophys. Res. Lett., 40, 4728-4733, https://doi.org/10.1002/grl.50880, 2013.

Barnes, E. A., Etienne, D. S., Giacomo, M., and Woollings, T.: Exploring recent trends in Northern Hemisphere blocking, Geophys. Res. Lett., 41, 638-644, https://doi.org/10.1002/2013GL058745, 2014.

Barnston, A. G. and Livezey, R. E.: Classification, seasonality and persistence of low-frequency atmospheric circulation patterns, Mon. Weather Rev., 115, 1083-1126, 1987.

Budikova, D.: Role of Arctic Sea Ice in Global Atmospheric Circulation: A review, Global Planet. Change, 68, 149-163, https://doi.org/10.1016/j.gloplacha.2009.04.001, 2009.

Budikova, D.: Northern Hemisphere Climate Variability: Character, Forcing Mechanisms, and Significance of the North Atlantic/Arctic Oscillation, Geography Compass, 6/7, 401-422, https://doi.org/10.1111/j.1749-8198.2012.00498.x, 2012.

Bueh, C. and Nakamura, H.: Scandinavian pattern and its climatic impact, Q. J. Roy. Meteor. Soc., 133, 2117-2131, https://doi.org/10.1002/qj.173, 2007.

Coumou, D., Petoukhov, V., Rahmstorf, S., Petri, S., and Schellnhuber, H. J.: Quasi-resonant circulation regimes and hemispheric synchronization of extreme weather in boreal summer, P. Natl. Acad. Sci. USA, 111, 12331-12336, https://doi.org/10.1073/pnas.1412797111, 2014.

Dee, D. P., Uppala, S. M., Simmons, A. J., Berrisford, P., Poli, P., Kobayashi, S., Andrae, U., Balmaseda, M. A., Balsamo, G., Bauer, P., Bechtold, P., Beljaars, A. C. M., van de Berg, L., Bidlot, J., Bormann, N., Delsol, C., Dragani, R., Fuentes, M., Geer, A. J., Haimberger, L., Healy, S. B., Hersbach, H., Hólm, E. V., Isaksen, L., Kållberg, P., Köhler, M., Matricardi, M., McNally, A. P., Monge-Sanz, B. M., Morcrette, J.-J., Park, B.-K., Peubey, C., de Rosnay, P., Tavolato, C., Thépaut, J.-N., and Vitart, F.: The ERA-Interim reanalysis: Configuration and performance of the data assimilation system, Q. J. Roy. Meteor. Soc., 137, 553-597, https://doi.org/10.1002/qj.828, 2011. 
Dobricic, S., Vignati, E., and Russo, S.: Large-Scale Atmospheric Warming in Winter and the Arctic Sea Ice Retreat, J. Climate, 29, 2869-2888, https://doi.org/10.1175/JCLI-D-15-0417.1, 2016.

Francis, J. A. and Vavrus, S. J.: Evidence linking Arctic amplification to extreme weather in mid-latitudes, Geophys. Res. Lett., 39, L06801, https://doi.org/10.1029/2012GL051000, 2012.

Gao, Y., Sun, J., Li, F., He, S., Sandven, S., Yan, Q., Zhang, Z., Lohmann, K., Keenlyside, N., Furevik, T., and Suo, L.: Arctic sea ice and Eurasian climate: A review, Adv. Atmos. Sci., 32, 92-114, https://doi.org/10.1007/s00376-014-0009-6, 2015.

Handorf, D., Jaiser, R., Dethloff, K., Rinke, A., and Cohen, J.: Impacts of Arctic sea ice and continental snow cover changes on atmospheric winter teleconnections, Geophys. Res. Lett., 42, 2367-2377, https://doi.org/10.1002/2015GL063203, 2015.

Hassanzadeh, P., Kuang, Z., and Farrell, B. F.: Responses of midlatitude blocks and wave amplitude to changes in the meridional temperature gradient in an idealized dry GCM, Geophys. Res. Lett., 41, 5223-5232, https://doi.org/10.1002/2014GL060764, 2014.

IPCC: Climate Change 2013: The Physical Science Basis. Contribution of Working Group I to the Fifth Assessment Report of the Intergovernmental Panel on Climate Change, edited by: Stocker, T. F., Qin, D., Plattner, G.-K., Tignor, M., Allen, S. K., Boschung, J., Nauels, A., Xia, Y., Bex, V., and Midgley, P. M., Cambridge University Press, Cambridge, United Kingdom and New York, NY, USA, 1535 pp., https://doi.org/10.1017/CBO9781107415324, 2013.

Jaagus, J.: Climatic changes in Estonia during the second half of the 20th century in relationship with changes in large-scale atmospheric circulation, Theor. Appl. Climatol., 83, 77-88, https://doi.org/10.1007/s00704-005-0161-0, 2006.

Jung, T., Doblas-Reyes, F., Goessling, H., Guemas, V., Bitz, C., Buontempo, C., Caballero, R., Jakobson, E., Jungclaus, J., Karcher, M., Koenigk, T., Matei, D., Overland, J., Spengler, T., and Yang, S.: Polar lower-latitude linkages and their role in weather and climate prediction, B. Am. Meteorol. Soc., 96, ES197-ES200, 2015.

Kug, J. S., Joeng, J. H., Jang, Y. S., Kim, B. M., Folland, C. K., Min, S. K., and Son, S. W.: Two distinct influences of Arctic warming on cold winters over North America and East Asia, Nat Geosci., 8, 759-762, https://doi.org/10.1038/ngeo2517, 2015.

Lee, M.-Y., Hong, C.-C., and Hsu, H.-H.: Compounding effects of warm sea surface temperature and reduced sea ice on the extreme circulation over the extratropical North Pacific and North America during the 2013-2014 boreal winter, Geophys. Res. Lett., 42, 1612-1618, https://doi.org/10.1002/2014GL062956, 2015.

Lehmann, A., Getzlaff, K., and Harlaß, J.: Detailed assessment of climate variability of the Baltic Sea area for the period 19582009, Clim. Res., 46, 185-196, https://doi.org/10.3354/cr00876, 2011.

Lehmann, A., Hoflich, K., Post, P., and Myrberg, K.: Pathways of deep cyclones associated with large volume changes (LVCs) and major Baltic inflows (MBIs), J MARINE SYST, 167, 11-18, https://doi.org/10.1016/j.jmarsys.2016.10.014, 2017.

Lim, Y. K.: The East Atlantic/West Russia (EA/WR) teleconnection in the North Atlantic: climate impact and relation to Rossby wave propagation, Clim. Dynam., 44, 3211, https://doi.org/10.1007/s00382-014-2381-4, 2015.
Liu, Z. and Alexander, M.: Atmospheric bridge, oceanic tunnel, and global climate teleconnections, Rev. Geophys., 45, RG2005, https://doi.org/10.1029/2005RG000172, 2007.

Moore, G. W. K., Renfrew, I. A., and Pickart, R.: Multi-decadal mobility of the North Atlantic Oscillation, J. Climate, 26, 24532466, https://doi.org/10.1175/JCLI-D-12-00023.1, 2013.

Overland, J. and Wang, M.: Large-scale atmospheric circulation changes associated with the recent loss of Arctic sea ice, Tellus A, 62, 1-9, https://doi.org/10.1111/j.1600-0870.2009.00421.x, 2010.

Overland, J., Francis, J. A., Hall, R., Hanna, E., Kim, S. J., and Vihma, T.: The melting Arctic and mid-latitude weather patterns: are they connected?, J. Climate, 28, 7917-7932, https://doi.org/10.1175/JCLI-D-14-00822.1, 2015.

Peings, Y. and Magnusdottir, G.: Response of the wintertime northern hemisphere atmospheric circulation to current and projected arctic sea ice decline: a numerical study with CAM5, J. Climate, 27, 244-264, https://doi.org/10.1175/JCLI-D-13-00272.1, 2014.

Perlwitz, J., Hoerling, M., and Dole, R.: Arctic Tropospheric Warming: Causes and Linkages to Lower Latitudes, J. Climate, 28, 2154-2167, https://doi.org/10.1175/JCLI-D-14-00095.1, 2015.

Petoukhov, V. and Semenov, V. A.: A link between reduced Barents-Kara sea ice and cold winter extremes over northern continents, J. Geophys. Res., 115, D21111, https://doi.org/10.1029/2009JD013568, 2010.

Petoukhov, V., Rahmstorf, S., Petri, S., and Schellnhube, H. J.: Quasiresonant amplification of planetary waves and recent Northern hemisphere weather extremes, P. Natl. Acad. Sci. USA, 110, 5336-5341, https://doi.org/10.1073/pnas.1222000110, 2013.

Rinke, A., Dethloff, K., Dorn, W., Handorf, D., and Moore, J. C.: Simulated Arctic atmospheric feedbacks associated with late summer sea ice anomalies, J. Geophys. Res.-Atmos., 118, 7698 7714, https://doi.org/10.1002/jgrd.50584, 2013.

Saha, S., Moorthi, S., Pan, H., Wu, X., Wang, J., Nadiga, S., Tripp, P., Kistler, R., Woollen, J., Behringer, D., Liu, H., Stokes, D., Grumbine, R., Gayno, G., Wang, J., Hou, Y., Chuang, H., Juang, H., Sela, J., Iredell, M., Treadon, R., Kleist, D., Delst, P., Keyser, D., Derber, J., Ek, M., Meng, J., Wei, H., Yang, R., Lord, S., Dool, H., Kumar, A., Wang, W., Long, C., Chelliah, M., Xue, Y., Huang, B., Schemm, J., Ebisuzaki, W., Lin, R., Xie, P., Chen, M., Zhou, S., Higgins, W., Zou, C., Liu, Q., Chen, Y., Han, Y., Cucurull, L., Reynolds, R., Rutledge, G., and Goldberg, M.: The NCEP Climate Forecast System Reanalysis, B. Am. Meteorol. Soc., 91, 1015-1057, https://doi.org/10.1175/2010BAMS3001.1, 2010.

Saha, S., Moorthi, S., Wu, X., Wang, J., Nadiga, S., Tripp, P., Behringer, D., Hou, Y., Chuang, H., Iredell, M., Ek, M., Meng, J., Yang, R., Mendez, M., Dool, H., Zhang, Q., Wang, W., Chen, M., and Becker, E.: The NCEP Climate Forecast System Version 2, J. Climate, 27, 2185-2208, https://doi.org/10.1175/JCLI-D-12$00823.1,2014$

Sato, K., Inoue, J., and Watanab, M.: Influence of the Gulf Stream on the Barents Sea ice retreat and Eurasian coldness during early winter, Environ. Res. Lett., 9, 084009, https://doi.org/10.1088/1748-9326/9/8/084009, 2014.

Screen, J. A. and Simmonds, I.: The central role of diminishing sea ice in recent Arctic temperature amplification, Nature, 464, 1334-1337, https://doi.org/10.1038/nature09051, 2010. 
Screen, J. A. and Simmonds, I.: Exploring links between Arctic amplification and mid-latitude weather, Geophys. Res. Lett., 40, 959-964, https://doi.org/10.1002/grl.50174, 2013.

Screen, J. A. and Simmonds, I.: Amplified mid-latitude planetary waves favour particular regional weather extremes, Nat. Clim. Change, 4, 704-709, 2014.

Screen, J. A., Deser, C., and Simmonds, I.: Local and remote controls on observed Arctic warming, Geophys. Res. Lett., 39, L10709, https://doi.org/10.1029/2012GL051598, 2012.

Screen, J. A., Deser, C., Simmonds, I., and Tomas, R.: Atmospheric impacts of Arctic sea-ice loss, 1979-2009: Separating forced change from atmospheric internal variability, Clim. Dynam., 43, 333-344, 2014.

Seierstad, I. A., Stephenson, D. B., and Kvamsto, N. G.: How useful are teleconnection patterns for explaining variability in extratropical storminess?, Tellus A, 59, 170-181, 2007.

Semenov, V. A. and Latif, M.: Nonlinear winter atmospheric circulation response to Arctic sea ice concentration anomalies for different periods during 1966-2012, Environ. Res. Lett., 10, 054020, https://doi.org/10.1088/1748-9326/10/5/054020, 2015.

Simmonds, I.: Comparing and contrasting the behaviour of Arctic and Antarctic sea ice over the 35-year period 1979-2013, Ann. Glaciol., 56, 18-28, https://doi.org/10.3189/2015AoG69A909, 2015.

Tang, Q., Zhang, X., Yang, X., and Francis, J. A.: Cold winter extremes in northern continents linked to Arctic sea ice loss, Environ. Res. Lett., 8, 014036, https://doi.org/10.1088/17489326/8/1/014036, 2013.
Thompson, D. W. J. and Wallace, J. M.: The Arctic Oscillation signature in the wintertime geopotential height and temperature fields, Geophys. Res. Lett., 25, 1297-1300, 1998.

Uotila, P., Vihma, T., and Haapala, J.: Atmospheric and oceanic conditions and the extremely mild Baltic Sea ice winter 2014/15, Geophys. Res. Lett., 42, 7740-7749, https://doi.org/10.1002/2015GL064901, 2015.

Vihma, T.: Effects of Arctic Sea Ice Decline on Weather and Climate: A Review, Surv. Geophys., 35, 1175-1214, https://doi.org/10.1007/s10712-014-9284-0, 2014.

Vihma, T., Cheng, B., and Uotila, P.: Linkages between Arctic sea ice cover, large-scale atmospheric circulation, and weather and ice conditions in the Gulf of Bothnia, Baltic Sea, Adv. Polar Sci., 25, 289-299, https://doi.org/10.13679/j.advps.2014.4.00289, 2014.

Wallace, J. M. and Gutzler, D. S.: Teleconnections in the Geopotential Height Field during the Northern Hemisphere Winter, Mon. Weather. Rev., 109, 784-812, https://doi.org/10.1175/15200493(1981)109<0784:TITGHF>2.0.CO;2, 1981.

Walsh, J. E.: Intensified warming of the Arctic: Causes and impacts on middle latitudes, Global Planet. Change, 117, 52-63, https://doi.org/10.1016/j.gloplacha.2014.03.003, 2014.

Wu, B. Y., Zhang, R. H., D'Arrigo, R., and Su, J.: On the Relationship between winter sea ice and summer atmospheric circulation over Eurasia, J. Climate, 26, 5523-5536, https://doi.org/10.1175/JCLI-D-12-00524.1, 2013. 